\title{
Nursing care of a patient diagnosed with malignant breast cancer during chemotherapy using ICNP ${ }^{\circledast}$ terminology
}

\author{
Opieka pielęgniarska nad pacjentką ze zdiagnozowanym nowotworem złośliwym piersi, \\ w czasie chemioterapii z wykorzystaniem terminologii ICNP®
}

\section{Paulina Mazurek', Piotr Pawłowski², Aneta Kościołek³, Klaudia Jakubowska ${ }^{3}$, Daria Makuch ${ }^{1}$, Joanna Borowik ${ }^{4}$}

'student studiów II ${ }^{\circ}$ kierunku pielęgniarstwo, Wydziału Nauk o Zdrowiu, Uniwersytet Medyczny w Lublinie
/Graduate of 2nd degree nursing studies, Faculty of Health Sciences, Medical University of Lublin
'student studiów I I kierunku pielęgniarstwo, Wydziału Nauk o Zdrowiu, Uniwersytet Medyczny w Lublinie
/Graduate of 1st degree nursing studies, Faculty of Health Sciences, Medical University of Lublin
'Zakład Podstaw Pielęgniarstwa i Dydaktyki Medycznej, Katedra Rozwoju Pielęgniarstwa, Wydziału Nauk o Zdrowiu, Uniwersytet Medyczny w Lublinie
/Department of Basic Nursing and Medical Teaching, Chair of Development in Nursing, Faculty of Health Sciences, Medical University of Lublin
student studiów jednolitych magisterskich kierunku lekarskiego, I Wydział Lekarski z Oddziałem Stomatologicznym, Uniwersytet Medyczny w Lublinie \begin{abstract}
${ }^{4}$ student studiów jednolitych magisterskich kierunku lekarskiego, I Wydział Lekarski z Oddziałem Stomatologicznym, Uniwersytet Medyczny w Lublinie
/Graduate of uniform master's degree, I Faculty of Medicine with Dentistry Division Medical University of Lublin
\end{abstract}
Aneta Kościołek: 0000-0001-5712-1629 Klaudia Jakubowska: 0000-0003-4120-5304

CORRESPONDING AUTHOR/AUTOR DO KORESPONDENCJI:

Paulina MM Lublinie

ul. Staszica 4/ 6, 20-081 Lublin

e-mail: mazurekpaulina20@gmail.com

\section{W CZASIE CHEMIOTERAPII Z WYKORZYSTANIEM TERMINOLOGII ICNPC}

Wstęp. Pielęgniarstwo onkologiczne jako specjalistyczna dziedzina powinno tworzyć szereg standardów, które zwiększą jakość opieki nad pacjentem. Nieuniknioną umiejętnością pielęgniarki jest tworzenie adekwatnych do stanu pacjenta diagnoz, opisujących holistycznie stan biopsychospołeczny podmiotu opieki.

Cel. Propozycja wykorzystania klasyfikacji ICNP ${ }^{\circledR}$ w procesie pielęgnowania pacjentki ze złośliwym nowotworem piersi w okresie chemioterapii.

Materiał i metody. W pracy wykorzystano metodę studium przypadku. Techniki badawcze zastosowane w pracy to: wywiad, obserwacja pielęgniarska, pomiar, analiza dokumentacji, zaś narzędzia to: Arkusz do gromadzenia danych o pacjencie, Skala akceptacji choroby (AIS), Kwestionariusz oceny ryzyka związanego ze stanem odżywienia (Nutritional Risk Score), skala oceny wystąpienia objawów ubocznych chemioterapii, ocena duszności, ocena nudności, ocena upadków, a także sala oceny nudności oraz wymiotów wg kryteriów WHO.

Wyniki. Po zebranym wywiadzie, dokonano oceny stanu biopsychospołecznego pacjentki. Wykorzystując uzyskane dane empiryczne stworzono diagnozy pielęgniarskie z wykorzystaniem terminologii referencyjnej ICNP ${ }^{\circledast}$. Wyszczególniono przedmiot opieki, interwencje pielęgniarskie, środki/ narzędzia oraz wynik opieki używając fraz z istniejących katalogów ICNP® . .

Wnioski. Wykorzystanie Międzynarodowej Klasyfikacji Diagnoz Pielęgniarskich ICNP ${ }^{\circledR}$ w kontekście opieki nad pacjentką ze zdiagnozowanym nowotworem piersi pozwala na wskazanie problemów pielęgniarskich takich jak: obrzęk limfatyczny, biegunka, niepokój, duszność wysiłkowa, wymioty, zaniepokojenie wizerunkiem ciała, ryzyko upadku.

Słowa kluczowe: rak piersi, chemioterapia, pielęgniarka, ICNP ${ }^{\circledR}$

\section{NURSING CARE OF A PATIENT DIAGNOSED WITH MALIGNANT BREAST CANCER DURING CHEMOTHERAPY USING ICNPO TERMNNOLOGY}

Introduction. Oncology nursing as a specialized field ought to develop a range of standards that will increase the quality of patient care. The indispensable ability of a nurse is to create patient-specific diagnoses that holistically describe the biopsychosocial status of the care focus.

Aim. The proposal to use the ICNP ${ }^{\circledR}$ classification in the process of nursing a patient with malignant breast cancer during chemotherapy. 
Material and methods. The case study method was used in the paper. The research techniques used in the work include an interview, nursing observation, measurement, documentation analysis. The tools include a sheet for collecting patient data, the Acceptance of IIIness Scale (AIS), Nutritional Risk Score questionnaire (NRS), scale of judgement of the occurrence of chemotherapy side effects, dyspnoea assessment, nausea assessment, fall rating as well as the Scale of nausea and vomiting judgement according to WHO criteria.

Results. After the interview, the biopsychosocial status of the patient was assessed. Using the obtained empirical data, nursing diagnoses were made using the ICNP ${ }^{\circledR}$ reference terminology. The focus of care, nursing interventions, means / tools and the result of care were listed using phrases from the existing ICNP ${ }^{\oplus}$ catalogs.

Conclusions. Using the International Classification of Nurses' Diagnosis ICNP ${ }^{\circledR}$ in the context of caring for a patient diagnosed with breast cancer allows to identify nursing problems such as: lymph edema, diarrhea, anxiety, exercise dyspnea, vomiting, concern about body image, risk of falling.

Key words: $\quad$ breast cancer, chemotherapy, nurse, ICNP ${ }^{\oplus}$

\section{INTRODUCTION}

Breast cancer is currently the most frequent cancer in women. Its malignant form accounts for $22 \%$ of all cases. However, the number of diagnosed patients keeps increasing every year, the highest percentage of them being women aged 50-69, which is associated with an increased risk of breast cancer until the seventh decade of life. Breast cancer, especially in Poland, is still characterized by high mortality, especially after the age of 50 (90\% deaths) [1].

One of the basic methods of breast cancer treatment is chemotherapy, which is associated with the occurrence of many side effects, significantly diminishing the quality of life of patients [1].

The nurse, as the person responsible for conducting the nursing process, is obliged to take up holistic care of the patient. Appropriate, adjusted to deficits, difficulties and problems of the patient, the nursing diagnosis can be formulated in two ways: by a traditional method and by using reference terminology, which is included in international classifications, inter alia, in $\mathrm{ICNP}^{\circledast}$ (International Classification for Nursing Practice) [2].

The ICNP ${ }^{\circledast}$ is a system developed by the International Council of Nurses (ICN), developed to unify the language of global nursing $[2,3,4]$.

The basic structure of ICNP ${ }^{\circledR}$ consists of 7 axes, which include: Action (A), Client (C), Focus (F), Judgment (J), Location (L), Means (M), Times (T) [3].

The methodology of developing the nursing process, including, most of all, diagnoses and nursing interventions, is based on the selection of terms coming from the individual ICNP ${ }^{\circledR}$ axes. For editing a proper nursing diagnosis, according to the ISO 18104: 2011 Standard, the concepts from the axis containing positive and negative diagnoses should be used (currently, the diagnosis is made on its own). If it is necessary to specify, it is recommended to use terms from other axes, e.g. Location or Judgment. In the case of action planning, it is obligatory to use the Action axis and at least one date specifying the "target/ object” from other axes of ICNP ${ }^{\circledR}$, excluding the axis of Judgment, in the case of intervention planning, there is also the possibility of further detailing [5].
AIM

The aim of the study was to present the use of ICNP ${ }^{\circledR}$ classification in the process of nursing a patient during chemotherapy who had been diagnosed with malignant breast cancer.

\section{MATERIALS AND METHODS}

The paper used a case study method with the following research techniques: an interview, nursing observation, measurement and documentation analysis. Also, the following research tools were applied: Sheet for patient data collection (aut. Zarzycka et al.), Acceptance of Illness Scale (AIS), Nutritional Risk Score questionnaire, Scale of dyspnea severity mMRC (Modified Medical Research Council), Scale of judgement of chemotherapy side effects, as well as the and tools found in Nursing Outcome Indicators. International Classification for Nursing Practice $\left(\mathrm{ICNP}^{\circledast}\right)$ Catalog, from the C-HOBIC system, such as dyspnoea assessment, nausea assessment, and fall assessment. For the assessment of nausea and vomiting, the nausea and vomiting scale according to the WHO criteria was additionally used.

The study was conducted in the Oncology Subward in the Provincial Hospital in Lublin from the $23^{\text {rd }}$ to $26^{\text {th }}$ of June 2016. The tests were performed in compliance with the patient's rights, the patient signed a written consent to undergo the tests.

The acceptance of illness scale is a research tool containing 8 statements describing the negative effects of the illness. The examined patient judges the intensity of the problem on the Likert scale (from 1 to 5), where 1 means „I definitely agree”, 5 - „I strongly disagree”[6].

The Nutritional Risk Score questionnaire is a point questionnaire, involving the deterioration of nutrition and the severity of existing illnesses, additional points are obtained for reaching the age of 70 [7].

The quality indicators of nursing care results according to C-HOBIC allow to assess the functioning, knowledge and skills of patients with the indication of ICNP ${ }^{\circledR}$ nursing diagnoses. The assessment of dyspnoea, the assessment of nausea, the assessment of falls consists in the classification of the patient to a given degree, depending on the severity and circumstances of the occurrence of the symptoms assessed [8]. 
The judgement Scale on the chemotherapy side effects lists the most common side effects of the use of chemotherapeutic agents as a treatment for cancer. The patient themselves judges their severity on a 10-point scale, where 1 means no symptoms, while 10 means the highest severity [9].

The WHO nausea judgement qualifies the patient for 5 possible degrees of their severity, depending on the nutritional disorders, the possibility of food and liquids intake, dehydration, and weight loss [9].

The vomiting judgement according to $\mathrm{WHO}$ rates the severity of vomiting in the patient, qualifying them for 5 possible groups depending on the number of episodes in the last 24 hours [9].

\section{Case report}

The patient, 61 years old, was admitted to the hospital for the final dose within a four-stage chemotherapy cycle. The social situation of the woman was rated as very good. The patient is married, she lives with her husband and granddaughter. She is currently retired. The patient does not complain about bad living conditions, she lives in a block of flats in the city. Although the patient is retired, she actively participates in family life. She spends a lot of time on her plot.

The patient has been suffering from cancer since the end of October 2016. The pathological thickening of breast tissue was detected during the self-examination during the evening bath. Before the detection, the patient did not experience any pain related to the presence of the lesion. The interview shows that the patient for some time felt tiredness in everyday activities, requiring no more physical effort. The patient regularly performed mammography screening. Since the last mammography until the detection of changes in self-examination has passed three months. The next day after the detection of tissue thickening, she went to the physician for mammography and breast ultrasonography. This diagnosis showed inconclusive changes in the upper outer right breast quadrant reaching a size of about $2 \mathrm{~cm}$. BAC biopsy performed in a patient by an oncologist confirmed the presence of cancer cells in histopathological examination. The patient underwent an operation of quadrantectomy and axillary lymphadenectomy at the Provincial Hospital in Lublin. During surgery, a fragment of tumor cells for pathology was tested, the result of which was confirmed by infiltrating, invasive ductal cancer. From December 2016, adjuvant treatment is continued, in the form of chemotherapy scheduled for 6 cycles, a preparation composed of doxorubicin (DOX) and CTX (cyclophosphamide).

On the day of the examination, the woman reports insomnia resulting from the fear of hospitalization. In addition, she claims that after the treatment she has problems with memory and forgets what she has just said. In addition, the patient has local edema located on the right forearm, resulting from the body's response to axillary lymphadenectomy. The patient reports numbness and tingling in the upper limbs.

Her nutritional status is correct, but the woman signals lack of appetite, increased thirst and dry mouth mucosa.
She does not accept meat foods and sweets, due to the occurring ailments. The woman reports that after the third dose of chemotherapy and the use of Zarzio ${ }^{\circ}$, her nausea, sometimes vomiting, and diarrhea occur through her parenteral route.

The overall judgement of the patient's condition based on the selected research tools is presented in Table 1.

Tab. 1. The findings from the adopted research tools and collected during the interview with the patient

\begin{tabular}{|c|c|}
\hline Research tool & Obtained findings \\
\hline $\begin{array}{l}\text { The Acceptance of Illness } \\
\text { Scale (AIS) }\end{array}$ & $\begin{array}{l}\text { The patient scored 21/40 points. She claims to have } \\
\text { accepted the illness to some extent. The biggest } \\
\text { problem is adapting to the limitations associated } \\
\text { with the illness. She does not feel useless to her } \\
\text { family and does not concern herself to be a burden to } \\
\text { them. Despite her illness, she feels a valuable person } \\
\text { in the full meaning of the word. She does not think } \\
\text { she is dependent on other people. According to the } \\
\text { woman, the illness caused the inability to perform } \\
\text { social roles to the extent they were performed } \\
\text { before diagnosing breast cancer. }\end{array}$ \\
\hline $\begin{array}{l}\text { Nutritional Risk Score } \\
\text { questionnaire }\end{array}$ & $\begin{array}{l}\text { The patient scored } 3 \text { points. Within } 4 \text { months, } \\
\text { the patient lost } 8 \mathrm{~kg} \text { and lost her appetite during } \\
\text { chemotherapy. }\end{array}$ \\
\hline $\begin{array}{l}\text { Scale of judgement } \\
\text { on the occurrence of } \\
\text { chemotherapy side } \\
\text { effects }\end{array}$ & $\begin{array}{l}\text { The patient lost her hair after the first chemotherapy, } \\
\text { judging this side effect as the greatest severity. } \\
\text { After chemotherapy, the patient is often affected } \\
\text { by diarrhea. Weakness and fatigue are a common } \\
\text { complication after the next cycle of chemotherapy. } \\
\text { The patient also experienced the side effects such as: } \\
\text { a metallic aftertaste, muscle pain (in the first week } \\
\text { after administration of cytostatic drugs), the dishes } \\
\text { lost their taste during chemotherapy, the patient } \\
\text { shows dry skin and breaking nails. The patient's } \\
\text { mental condition is defined as normal, with periodic } \\
\text { anxiety and lower self-esteem, mainly due to lack of } \\
\text { scalp hair. The patient feels motivated to overcome } \\
\text { the illness. }\end{array}$ \\
\hline Dyspnoea assessment & $\begin{array}{l}\text { The severity of symptoms and the circumstances of } \\
\text { their occurrence qualify the first-degree dyspnoea } \\
\text { - shortness of breath Absent at rest, present at } \\
\text { moderate activity. In addition, the patient has } \\
\text { a dry cough. }\end{array}$ \\
\hline Nausea assesment & $\begin{array}{l}\text { The severity of symptoms qualifies the patient } \\
\text { to grade III nausea - Serious nausea, disturbing } \\
\text { everyday in eating and / or any activity. }\end{array}$ \\
\hline Fall rating & $\begin{array}{l}\text { The patient is at risk of falling due to existing side } \\
\text { effects of chemotherapy and one fall within } 90 \text { days } \\
\text { before the evaluation. }\end{array}$ \\
\hline $\begin{array}{l}\text { The scale of nausea } \\
\text { judgement according } \\
\text { to WHO criteria }\end{array}$ & $\begin{array}{l}\text { The final findings showed the 3rd degree indicating } \\
\text { the occurrence of intense nausea, including } \\
\text { disordered intake of liquid and solid food. }\end{array}$ \\
\hline $\begin{array}{l}\text { The scale of vomiting } \\
\text { judgement according } \\
\text { to WHO criteria }\end{array}$ & $\begin{array}{l}\text { The patient was qualified for the } 2 \text { nd degree. } \\
\text { The patient complains that from } 2 \text { to } 5 \text { episodes } \\
\text { occur per } 24 \text { hours during the adjuvant therapy. }\end{array}$ \\
\hline
\end{tabular}

\section{RESULTS}

In the course of the overall judgement of the patient's general condition, 7 nursing diagnoses were made and appropriate interventions were selected for them, using the ICNP ${ }^{\circledR}$ classification in the online version [10]. 
Diagnosis 1. lymphoedema [10030003]; right [10017234]; forearm [10008164]

Focus: lymphoedema [10031661];

Nursing interventions:

- Judging the oedema [10045177];

- Teaching about exercises [10040125];

- Promoting compliance with the exercise regime [10041628];

- Teaching about rehabilitation [10033017];

- Teaching about the oedema [10045183];

- Managing the oedema [10036793].

Findings: no peripheral oedema [10029031]

Diagnosis 2. diarrhea [10000630];

Focus: diarrhea [10005933];

Nursing interventions:

- Judging the risk of dehydration [10040932];

- Teaching about the diet regime [10026525];

- Cooperation in a liquid therapy [10033093] and in an electrolyte therapy [10030930];

- Judging liquids intake [10044176];

- Monitoring the treatment response [10032109];

- Judging diarrhea [10043656];

- Monitoring the body mass [10032121];

- Teaching about diarrhea management [10043660];

- Evaluation of the digestive system status [10034007];

Findings: no diarrhea [10040063]

Diagnosis 3. insomnia [10000477]

Focus: insomnia [10002429];

Nursing interventions:

- Judgement of psychological status [10030734];

- Managing anxiety [10031711];

- Demonstrating relaxation techniques [10024365];

- Judging sleep [10036764];

- Relaxation therapy [10039191];

Findings: diminishing anxiety [10027858]

Diagnosis 4. dyspnea on exertion (functional) [10029414]

Focus: dyspnea on exertion (functional) [10008268]

Nursing interventions:

- Judgement of breathing status [10036786];

- Measuring breaths [10046338];

- Encouraging rest [10041415].

Findings: no dyspnea [10029264]

Diagnosis 5. vomiting [10025981]

Focus: vomiting [10020864]

Nursing interventions:

- Monitoring nutrition [10036032];

- Monitoring body mass [10032121];

- Teaching about dietary needs [10046533];

- Assesing liquid balance [10037881];

- Judging nutritional status [10030660];

- Judging the risk of dehydration [10040932];

- The oral cavity care [10032184];

- Positioning the patient [10014761];

- Ensuring privacy [10026399];

- Ensuring emotional support [10027051].

Findings: no nausea episodes [10029181]
Diagnosis 6. the risk of fall [10015122]

Focus: fall [10007512]

Nursing interventions:

- Demonstrating the methods of fall prevention [10040248];

- Monitoring the risk of fall [10037442];

- Judging the risk of fall [10023520];

- Delivery of security devices [10024527].

Finding: no falls [10034704]

Diagnosis 7. concern about the body's image [10001079]

Focus: personal image [10017776]

Nursing interventions:

- Supporting psychical status [10019161];

- Providing emotional support [10027051];

- Promoting self-esteem [10024455];

- Judging psychological status [10030734];

- Judging the acceptance of health status [10026249].

Findings: positive personal image [10027108]

\section{DISCUSSION}

In Poland, the nurse's practice of ICNP ${ }^{\circledR}$ nursing diagnosis classification in the field of creating diagnoses, interventions and care results is at the pilot stage of introducing it in selected units of the health care system. Since the introduction of ICNP ${ }^{\circledR}$ in other countries, mainly Western Europe, a gradual increase in the number of publications showing the use of this classification in creating processes of nursing various illness entities has been noticed [1116]. The introduction of $\mathrm{ICNP}^{\circledR}$ in Poland could unify the language of nursing diagnoses, increase the efficiency of the nursing team's work, thus shortening the time required to complete traditional documentation. The nurse could save the time spent on establishing contact with the patient, conducting therapeutic talks, which in the case of a health crisis that is cancer can help to obtain measurable results of treatment, through high-quality patient support in the psychosocial sphere [16, 17].

During the implementation of the research process, it was noticed that the use of ready-made catalogs dedicated to specific nursing specialties made it possible to move faster through the entire classification, thanks to the isolation of care and therapeutic problems adequate to a given department. According to Babska, it is essential to conduct clinical studies aimed at identifying diagnoses and interventions that occur most frequently in a given ward. This will allow for proper inference regarding the applied activities, and thus obtaining decent findings in the holistic nursing process in the future $[14,16]$. Unfortunately, there is no catalog on nursing nursing, so you should use the available catalogs or independently create a nursing process using ICNP ${ }^{\circledR}$, which was made in this study. Ikwanty and Dobrowolska claim that for the proper development and implementation of ICNP ${ }^{\circledR}$ in practice, it is necessary to create catalogs, which are a response to the needs of a given nursing area, including, among others, a catalog dedicated to oncological wards [13]. 
According to Furtado LG et al., the use of ICNP ${ }^{\circledR}$ in nursing practice brings many benefits including, inter alia, improving communication between nursing teams and employees of the health care system both in the ward and other medical facilities, systematizing the process of collecting information, obtaining an assessment of nursing care results, improving the quality of nursing skills judgement, increasing the transparency of nursing activities as well as increasing the quality of patient care [ 18]. Referring the aforementioned benefits to the process of nursing patients during periods of anticancer therapy, attention should be paid to the fact that there are numerous nursing problems related to the occurrence of biological deficiencies, side effects of the drugs used, psychological, social and spiritual difficulties. The use of ICNP ${ }^{\circledR}$ can thus facilitate the process of diagnosing and planning care for a patient hospitalized in cancer departments.
Before the implementation of the international classification of ICNP ${ }^{\otimes}$ diagnoses, it is undoubtedly important to familiarize the nursing environment with its structure in advance, and also with the methodology of creating the care process according to ICN and ISO, so that every member of the nursing team could effectively navigate the system and catalogs and create a proper nursing process [5].

\section{CONCLUSIONS}

- The implementation of the research process allowed to indicate the following nursing problems according to the ICNP ${ }^{\circledR}$ classification: lymphedema, diarrhea, anxiety, exercise dyspnea, vomiting, concern over the body image, risk of falling.

- Presentation of the practical use of ICNP ${ }^{\circledR}$ in the process of nursing a patient diagnosed with cancer may contribute to a better understanding of the classification by the nursing community.

\section{Opieka pielęgniarska nad pacjentką ze zdiagnozowanym nowotworem złośliwym piersi, w czasie chemioterapii z wykorzystaniem terminologii ICNP ${ }^{\circledR}$}

\section{WSTĘP}

Nowotwór piersi jest obecnie najczęstszym występującym nowotworem u kobiet. Jego postać złośliwa stanowi $22 \%$ wszystkich zachorowań. Jednak z roku na rok wzrasta liczba zdiagnozowanych chorych, największy ich odsetek stanowią kobiety w wieku 50-69 lat, co wiąże się ze zwiększaniem ryzyka wystąpienia raka piersi, aż do siódmej dekady życia. Rak piersi nadal, szczególnie na terenie Polski, cechuje się wysoką śmiertelnością, w szczególności po 50 r.ż. (90\% zgonów) [1].

Jedną z podstawowych metod leczenia nowotworu piersi jest chemioterapia, która wiąże się z wystąpieniem wielu skutków ubocznych, znacząco obniżających jakość życia pacjentów [1].

Pielęgniarka, jako osoba odpowiedzialna za prowadzenie procesu pielęgnowania, jest zobowiązana do sprawowania holistycznej opieki nad pacjentem. Stosowna, odpowiadająca deficytom, trudnościom, problemom chorego diagnoza pielęgniarska może być formułowana dwojako: metodą tradycyjną oraz $\mathrm{z}$ wykorzystaniem terminologii referencyjnej, która zawarta jest w międzynarodowej klasyfikacji diagnoz pielęgniarskich ICNP ${ }^{\circledR}$ (Międzynarodowa Klasyfikacja Praktyki Pielegniarskiej, ang. International Classification for Nursing Practice) [2].

$\mathrm{ICNP}^{\oplus}$ to system opracowany przez Międzynarodową Radę Pielęgniarek (ICN - International Council of Nurses), stworzony w celu ujednolicenia języka ogólnoświatowego pielęgniarstwa $[2,3,4]$.
Struktura podstawowa ICNP ${ }^{\circledR}$ złożona jest z 7 osi, do których należą: Działanie (A - Action), Klient (C - Client), Przedmiot (F - Focus), Osąd (J - Judgment), Lokalizacja (L - Location), Środki (M - Means ), Czas (T - Times). [4].

Metodologia tworzenia procesu pielęgnowania, $\mathrm{w}$ tym przede wszystkim diagnoz oraz interwencji pielęgniarskich, opiera się na wyborze terminów wychodzących się z poszczególnych osi ICNP ${ }^{\circledR}$. Dla redagowania właściwej diagnozy pielęgniarskiej, według Standardu ISO 18104:2011 należy wykorzystać pojęcia z osi zawierającej diagnozy poztywne i negatywne (aktualnie odchodzi się od samodzielnego budowania diagnoz). W przypadku konieczności doszczegółowienia zaleca się stosowanie terminów z innych osi np. Lokalizacja, czy Osąd. W przypadku planowania działań obowiązkowo należy skorzystać z osi Działania oraz co najmniej jeden termin określający „cel/przedmiot”, pochodzący z innych osi ICNP ${ }^{\circledR}$, z wyłączeniem osi Osąd, w przypadku planowania interwencji również istnieje możliwość doszczegółowienia [5].

\section{CEL PRACY}

Celem przeprowadzonego badania jest prezentacja wykorzystania klasyfikacji ICNP ${ }^{\circledast}$ w procesie pielęgnowania pacjentki ze zdiagnozowanym złośliwym nowotworem piersi podczas chemioterapii. 


\section{MATERIAŁ I METODYKA}

W pracy posłużono się metodą studium indywidualnego przypadku z wykorzystaniem następujących technik badawczych: wywiad, obserwacja pielęgniarska, pomiar, analiza dokumentacji. Wykorzystano również takie narzędzia badawcze, jak: Arkusz do gromadzenia danych o pacjencie (aut. Zarzycka i in.), Skala akceptacji choroby (AIS), Kwestionariusz oceny ryzyka związanego ze stanem odżywienia (Nutritional Risk Score), Skala oceny wystąpienia objawów ubocznych chemioterapii, a także narzędzia znajdujące się w Nursing Outcome Indicators. International Classification for Nursing Practice ( ICNP ${ }^{\circ}$ ) Catalogue, z systemu C - HOBIC takie jak: ocena duszności, ocena nudności, ocena upadków. Dla oceny nudności i wymiotów wykorzystano dodatkowo skalę oceny nudności oraz wymiotów wg kryteriów WHO.

Badanie zostało przeprowadzone na Pododdziale Onkologicznym w Szpitalu Wojewódzkim w Lublinie od 23 do 26 czerwca 2016 r. Badania były przeprowadzone w zgodzie poszanowania praw pacjenta, pacjentka podpisała pisemną zgodę na przeprowadzenie badań.

Skala akceptacji choroby jest narzędziem badawczym zawierającym 8 stwierdzeń opisujących negatywne skutki choroby. Badany pacjent ocenia występujące natężenie problemu w skali Likerta (od 1 do 5), gdzie 1 oznacza „zdecydowanie zgadzam się", 5 natomiast - zdecydowanie nie zgadzam się [6].

Kwestionariusz oceny ryzyka związanego ze stanem odżywienia (Nutritional Risk Score) jest punktowym kwestionariuszem, biorącym pod uwagę pogorszenie stanu odżywiania oraz nasilenie występujących chorób, dodatkowe punkty otrzymuje się za ukończenie 70. roku życia [7].

W Skali oceny wystąpienia objawów ubocznych chemioterapii wymienione są najczęstsze skutki uboczne stosowanie chemioterapeutyków jako sposobu leczenia nowotworu. Chory samodzielnie ocenia stopień ich nasilenia w 10. stopniowej skali, gdzie 1 oznacza brak objawów, 10 natomiast - największe nasilenie [9].

Wskaźniki jakości wyników opieki pielęgniarskiej według C-HOBIC pozawalają na ocenę funkcjonowania, wiedzy i umiejętności pacjentów ze wskazaniem diagnoz pielęgniarskich ICNP. Ocena duszności, ocena nudności, ocena upadków polega na kwalifikacji pacjenta do danego stopnia, w zależności od nasilenia oraz okoliczności występowania ocenianych objawów [8].

Ocena nudności wg WHO kwalifikuje chorego do 5 możliwych stopni ich nasilenia, w zależności od zaburzeń odżywienia, możności przyjmowania pokarmów oraz płynów, odwodnienia, utraty masy ciała [9].

Ocena wymiotów wg WHO ocenia intensywność wymiotów u chorego, kwalifikując go do 5 możliwych grup w zależności od ilości epizodów w czasie ostatnich 24h [9].

\section{Opis przypadku}

Pacjentka, lat 61 przyjęta na oddział w celu przyjęcia ostatniej, z sześciu dawek chemioterapii. Sytuacja społeczna kobiety oceniono jako bardzo dobrą. Pacjentka jest mężatką, mieszka wspólnie z mężem i wnuczką. Aktualnie jest na emeryturze. Pacjentka nie skarży się na złe warunki mieszkalne, mieszka w bloku, w mieście. Pomimo,

że pacjentka jest na emeryturze aktywnie uczestniczy w życiu rodzinnym. Dużo czasu spędza na swojej działce.

Pacjentka od końca października 2016 r. zmaga się $\mathrm{z}$ chorobą nowotworową. Patologiczne zgrubienie tkanek piersi chora piersi wykryła podczas samobadania, $\mathrm{w}$ czasie wieczornej kąpieli. Przed wykryciem chora nie odczuwała dolegliwości bólowych związanych z obecnością zmiany. $\mathrm{Z}$ przeprowadzonego wywiadu wynika, iż pacjentka od jakiegoś czasu czuła zmęczenie przy czynnościach dnia codziennego, nie wymagającym większego wysiłku fizycznego. Pacjentka wykonywała regularnie badania mammograficzne. Od czasu ostatniej mammografii do czasu wykrycia zmiany w samobadaniu minęły 3 miesiące. Chora dnia następnego po wykryciu zgrubienia tkanek udała się do lekarza w celu wykonania badania mammograficznego, a także na USG piersi. Diagnostyka ta wykazała niepojące zmiany w górnym zewnętrznym kwadrancie piersi prawej osiągające rozmiar około $2 \mathrm{~cm}$. Biopsja BAC wykonana u pacjentki przez lekarza onkologa

Tab. 1. Rezultaty oceny stanu pacjentki wg przyjętych narzędzi badawczych

\begin{tabular}{|c|c|}
\hline Narzędzie badawcze & Uzyskany wynik \\
\hline $\begin{array}{l}\text { Skala akceptacji } \\
\text { choroby (AIS) }\end{array}$ & $\begin{array}{l}\text { Pacjentka uzyskałą } 21 / 40 \text { pkt. twierdzi, że w pewnym } \\
\text { stopniu zgadza się z chorobą. Najwięeszzy problem ma } \\
\text { z przystosowaniem się do ograniczeń związanych z } \\
\text { chorobą. Nie czuje się niepotrzebna rodzinie oraz nie } \\
\text { uważa siebie za ciężar rodziny. Pomimo choroby czuję } \\
\text { się pełnowartósiowym człowiekiem. Nie uważa, że jest } \\
\text { zależnych od innych ludzi. Zdaniem kobiety choroba } \\
\text { spowodowała niemożność pełnienia ról społecznych, } \\
\text { w takim wymiarze jak przed zdiagnozowaniem } \\
\text { nowotworu piersi. }\end{array}$ \\
\hline $\begin{array}{l}\text { Kwestionariusz oceny } \\
\text { ryzyka związanego } \\
\text { ze stanem odżywienia } \\
\text { (Nutritional Risk Score) } \\
\end{array}$ & $\begin{array}{l}\text { Pacjentka uzyskała } 3 \text { punkty. W ciągu } 4 \text { miesięcy } \\
\text { pacjentka schudła } 8 \text { kg oraz straciła apetyt podczas } \\
\text { leczenia chemioterapią. }\end{array}$ \\
\hline $\begin{array}{l}\text { Skala oceny } \\
\text { wystąpienia } \\
\text { objawów ubocznych } \\
\text { chemioterapii }\end{array}$ & $\begin{array}{l}\text { Pacjentka straciła włosy po pierwszej chemioterapii, } \\
\text { oceniając ten objaw uboczny na największe nasilenie. } \\
\text { Po chemioterapii często u pacjentki występuje biegunka. } \\
\text { Osłabienie oraz zmęczenie jest częstym powikłaniem } \\
\text { po przyjęciu kolejnego cyklu chemioterapii. U pacjentki } \\
\text { występują również uboczne objawy jak: metaliczny } \\
\text { posmak, bóle mięśni ( w pierwszym tygodniu po } \\
\text { podaniu cytostatyków), potrawy straciły dla niej smak } \\
\text { podczas chemioterapii, u pacjentki widoczne jest sucha } \\
\text { skóra oraz łamiące się paznokcie. Stan psychicznej chorej } \\
\text { określono jako prawidłowy, z występującym okresowym } \\
\text { lękiem oraz obniżeniem poczucia własnej wartości, } \\
\text { głównie z powodu braku owłosienia głowy. Chora czuje } \\
\text { motywację do przezwyciężenia choroby. }\end{array}$ \\
\hline Ocena duszności & $\begin{array}{l}\text { Nasilenie objawów oraz okoliczności ich wystąpienia } \\
\text { kwalifikują chorą do I stopnia duszności - duszność } \\
\text { Nieobecna przy odpoczynku, obecna przy umiarkowanej } \\
\text { aktywności. Ponad to u pacjentki występuje suchy kaszel. }\end{array}$ \\
\hline Ocena nudności & $\begin{array}{l}\text { Nasilenie objawów kwalifikują chorą do III stopnia } \\
\text { nudności - Nudności ciężkie, przeszkadzające codziennie } \\
\text { w jedzeniu i/ lub jakiejkolwiek aktywności. } \\
\end{array}$ \\
\hline Ocena upadków & $\begin{array}{l}\text { U pacjentki występuje ryzyko upadku z powodu } \\
\text { istniejących objawów ubocznych chemioterapii oraz } \\
\text { wystąpienia jednego upadku w przeciągu } 90 \text { dni przed } \\
\text { dokonaniem oceny. }\end{array}$ \\
\hline $\begin{array}{l}\text { Skalę oceny nudności } \\
\text { wg kryteriów WHO }\end{array}$ & $\begin{array}{l}\text { Końcowy wynik wyniósł III stopień świad zzący o } \\
\text { występowaniu intensywnych nudności łąznie z zaburzonym } \\
\text { przyjmowaniu pokarmów płynnych jak i stałych. }\end{array}$ \\
\hline $\begin{array}{l}\text { Skalę oceny wymiotów } \\
\text { wg kryteriów WHO }\end{array}$ & $\begin{array}{l}\text { Pacjentkę zakwalifikowano do Il stopnia. Pacjentka } \\
\text { skarży się, że podczas leczenia uzupełniającego } \\
\text { występują od } 2 \text { do } 5 \text { epizodów na } 24 \text { h. }\end{array}$ \\
\hline
\end{tabular}


potwierdziła, w badaniu histopatologicznym obecność komórek nowotworowych. Pacjentka przebyła zabieg operacyjny kwadrantektomii i limfadenektomii pachowej w Szpitalu Wojewódzkim w Lublinie. Podczas zabiegu operacyjnego pobrano fragment komórek nowotworowych przeznaczonych do badania patomorfologicznego, którego wynik potwierdził nowotwór naciekający, inwazyjny przewodowy Od grudnia 2016 r. kontynuowane jest leczenie uzupełniające, w postaci chemioterapii zaplanowaną na 6 cykli, preparatem złożonym z doksorubicyny (DOX) oraz CTX (cyklofosfamid).

W dniu badania kobieta zgłasza występowanie bezsenności wynikającej z lęku przed hospitalizacją. Dodatkowo twierdzi, iż po zastosowanym leczeniu ma problemy z pamięcią oraz zapomina, o czym mówiła przed chwilą. Ponadto u chorej występują obrzęki miejscowe zlokalizowane na prawym przedramieniu, powstałe w wyniku reakcji organizmu na zabieg limfadenektomii pachowej. Pacjentka zgłasza drętwienie i mrowienie kończyn górnych.

Stan odżywienia jest prawidłowy, ale kobieta sygnalizuje brak apetytu, wzmożone pragnienie i wysychanie błon śluzowych jamy ustnej. Nie przyjmuje pokarmów mięsnych i słodyczy, ze względu na występujące dolegliwości. Kobieta zgłasza, że po podaniu trzeciej dawki chemioterapii oraz przyjęciu leku Zarzio ${ }^{\circledast}$, drogą parenteralną występują u niej nudności, czasem wymioty, a także biegunka.

Całościowa ocena stanu pacjentki w oparciu o wybrane narzędzia badawcze została przedstawiona w Tabeli 1 .

\section{WYNIKI}

W przebiegu przeprowadzonej całościowej oceny stanu ogólnego pacjentki postawiono 7 diagnoz pielęgniarskich oraz dobrano do nich adekwatne interwencje, korzystając $\mathrm{z}$ klasyfikacji ICNP ${ }^{\circledast} \mathrm{w}$ wersji on-line [10].

Diagnoza 1. obrzęk limfatyczny [10030003]; prawe [10017234]; przedramię [10008164]

Przedmiot: obrzęk limfatyczny [10031661];

Interwencje pielęgniarskie:

- Ocenianie obrzęku [10045177];

- Nauczanie o ćwiczeniach [10040125];

- Promowanie przestrzegania reżimu ćwiczeń[10041628];

- Nauczanie o rehabilitacji [10033017];

- Nauczanie o obrzęku [10045183];

- Zarządzanie obrzękiem [10036793].

Wynik: bez obrzęków obwodowych [10029031]

Diagnoza 2. biegunka [10000630];

Przedmiot: biegunka [10005933];

Interwencje pielęgniarskie:

- Ocenianie ryzyka odwodnienia [10040932];

- Nauczanie o reżimie diety [10026525];

- Współdziałanie w terapii płynami [10033093] i współdziałanie przy terapii elektrolitami [10030930];

- Ocenianie spożycia płynów [10044176];

- Monitorowanie odpowiedzi na leczenie [10032109];

- Ocenianie biegunki [10043656];

- Monitorowanie masy ciała [10032121];

- Nauczanie o zarządzaniu biegunką [10043660];
- Ewaluacja statusu przewodu pokarmowego [10034007];

Wynik: bez biegunki [10040063]

Diagnoza 3. niepokój [10000477];

Przedmiot: niepokój [10002429]

Interwencje pielęgniarskie:

- Ocenianie statusu psychologicznego [10030734];

- Zarządzanie niepokojem [10031711];

- Demonstrowanie technik relaksacyjnych [10024365];

- Terapia relaksacyjna [10039191];

Wynik: zmniejszający się niepokój [10027858]

Diagnoza 4. duszność wysiłkowa (funkcjonalna) [10029414];

Przedmiot: duszność wysiłkowa (funkcjonalna) [10008268];

Interwencje pielęgniarskie:

- Ocenianie statusu oddechowego [10036786];

- Zmierzenie oddechów [10046338];

- Zachęcanie do odpoczynku [10041415].

Wynik: bez duszności [10029264]

Diagnoza 5. wymioty [10025981]

Przedmiot: wymioty [10020864]

Interwencje pielęgniarskie:

- Monitorowanie odżywiania [10036032];

- Monitorowanie wagi ciała [10032121];

- Nauczanie o potrzebach dietetycznych [10046533];

- Ocenianie równowagi płynów [10037881];

- Ocenianie statusu odżywienia [10030660];

- Ocenianie ryzyka odwodnienia [10040932];

- Pielęgnacja jamy ustnej [10032184];

- Pozycjonowanie pacjenta [10014761];

- Zapewnienie prywatności [10026399];

- Zapewnienie wsparcia emocjonalnego [10027051].

Wynik: bez wymiotów [10029181]

Diagnoza 6. ryzyko upadku [10015122]

Przedmiot: upadek [10007512]

Interwencje pielęgniarskie:

- Demonstrowanie metod prewencji upadków [10040248];

- Monitorowanie ryzyka upadku [10037442];

- Ocenianie ryzyka upadków [10023520];

- Dostarczenie urządzeń zabezpieczających [10024527].

Wynik: brak upadku [10034704]

Diagnoza 7. zaniepokojenie wizerunkiem ciała [10001079];

Przedmiot: wizerunek własny [10017776];

Interwencje pielęgniarskie:

- Wspieranie statusu psychicznego [10019161]

- Dostarczenie wsparcia emocjonalnego [10027051]

- Promowanie poczucia własnej wartości [10024455]

- Ocenianie statusu psychologicznego[10030734]

- Ocenianie akceptacji statusu zdrowotnego [10026249]

Wynik: pozytywny wizerunek własny [10027108] 
Paulina Mazurek, Piotr Pawłowski, Aneta Kościołek, Klaudia Jakubowska, Daria Makuch, Joanna Borowik

\section{OMÓWIENIE}

W Polsce wykorzystanie w praktyce pielęgniarki klasyfikacji diagnoz pielęgniarskich ICNP ${ }^{\circledR} \mathrm{w}$ zakresie tworzenia diagnoz, interwencji i wyników opieki jest na etapie pilotażowego wprowadzania jej w wybranych jednostkach systemu opieki zdrowotnej. Od czasu wprowadzenia ICNP ${ }^{\circledR}$ w innych krajach, głównie Europy Zachodniej, można zauważyć stopniowe zwiększanie się liczby publikacji, ukazujących zastosowanie tej klasyfikacji w tworzeniu procesów pielęgnowana pacjentów $\mathrm{z}$ różnorodnymi jednostkami chorobowymi. Jednakże brak jest literatury odnoszącej się do pielęgniarstwa onkologicznego, pielęgnacji pacjenta ze zdiagnozowaną chorobą nowotworową [11- 16]. Wprowadzenie ICNP $^{\circ} \mathrm{w}$ Polsce mogłoby ujednolicić język diagnoz pielęgniarskich, służyć zwiększeniu wydajność pracy zespołu pielęgniarskiego, skracając tym samym czas przeznaczony na wypełnienie tradycyjnej dokumentacji. Zaoszczędzony czas pielęgniarka mogłoby przeznaczyć na nawiązywanie kontaktu z pacjentem, przeprowadzanie rozmów terapeutycznych, które w przypadku kryzysu zdrowotnego jakim jest choroba nowotworowa może wspomóc uzyskanie wymiernych wyników leczenia, przez wysokojakościowe wsparcie pacjenta $\mathrm{w}$ sferze psychospołecznej $[16,17]$.

Podczas realizacji procesu badawczego zauważono, iż korzystanie z gotowych katalogów dedykowanych konkretnym pielęgniarskim specjalizacjom umożliwił szybsze poruszanie się po całej klasyfikacji, dzięki wyodrębnieniu adekwatnych do danego oddziału problemów opiekuńczo - terapeutycznych. Według Babskiej potrzebne jest przeprowadzenie badań klinicznych mających na celu wskazanie diagnoz oraz interwencji, które na danym oddziale występują najczęściej. Pozwoli to na właściwe wnioskowanie dotyczace stosowanych działań, a w konsekwencji w przyszłości uzyskanie wyższej jakości opieki pielęgniarskiej $[14,16]$. Niestety brak jest katalogu dotyczącego pielęgniarstwa onkologicznego, należy więc korzystać $\mathrm{z}$ dostępnych katalogów bądź samodzielnie tworzyć proces pielęgnowania $\mathrm{z}$ wykorzystaniem ICNP ${ }^{\circledR}$, co uczyniono w niniejszym opracowaniu. Ikwanty oraz Dobrowolska twierdzą, iż dla prawidłowego rozwoju oraz implementacji w praktyce ICNP ${ }^{\circledR}$ niezbędne jest tworzenie katalogów, będących odpowiedzią na potrzeby danego obszaru pielęgnowania, w tym między innymi katalogu dedykowanego oddziałom onkologicznym [13].

Według Furtado LG i wsp. stosowanie ICNP ${ }^{\circ}$ w praktyce pielęgniarskiej przynosi wiele korzyści, obejmujących m.in. polepszenie komunikacji między zespołami pielęgniarskimi i pracownikami systemu ochrony zdrowia zarówno na oddziale jak i innych placówkach medycznych, usystematyzowanie procesu zbierania informacji, uzyskiwania oceny wyników pielęgniarskiej opieki, polepszenie jakości oceny kompetencji pielęgniarskich, zwiększenie poziomu widoczności czynności pielęgniarskich, jak i zwiększenie jakości świadczonej opieki nad pacjentem [18]. Odnosząc wyżej wymienione korzyści do procesu pielęgnowania pacjentów w okresach terapii przeciwnowotworowej, należy zwrócić uwagę na fakt wystę- powania licznych problemów pielęgnacyjnych związanych z występowaniem deficytów biologicznych, objawów ubocznych stosowanych leków, trudności psychologicznych, społecznych oraz duchowych. Wykorzystanie ICNP ${ }^{\circ}$ może ułatwić więc proces diagnozowania i planowania opieki nad pacjentem hospitalizowanym na oddziałach onkologicznych.

Przed implementacją międzynarodowej klasyfikacji diagnoz ICNP ${ }^{\oplus}$ bez wątpienia ważne jest wcześniejsze zaznajomienie środowiska pielęgniarskiego z jej strukturą, a także metodologią tworzenia procesu pielęgnowania wg zasad standardu ICN oraz ISO, tak aby każdy członek zespołu pielęgniarskiego mógł efektywnie poruszać się po systemie, katalogach oraz tworzył prawidłowy proces pielęgnowania [5].

\section{WNIOSKI}

Realizacja procesu badawczego pozwoliła na wskazanie następujących problemów pielęgniarskich wg klasyfikacji ICNP ${ }^{\otimes}$ : obrzęk limfatyczny, biegunka, niepokój, duszność wysiłkowa, wymioty, zaniepokojenie wizerunkiem ciała, ryzyko upadku.

Prezentacja praktycznego wykorzystania $\mathrm{ICNP}^{\circledR} \mathrm{w}$ procesie pielęgnowania pacjenta ze zdiagnozowanym nowotworem może przyczynić się do lepszego poznania klasyfikacji przez środowisko pielęgniarskie.

\section{REFERENCES/PIŚMIENNICTWO}

1. Jassem J, et al. Breast cancer. Oncol Clin Pract. 2018; 14. D0I: 10.5603/0CP.2018.0027.

2. Andruszkiewicz A. i wsp. ICNP ${ }^{\circledR}$ - standardowe rozwiązania w praktyce i standardy pracy pielęgniarskiej. [w:] Kilańska D, red. Międzynarodowa Klasyfikacja Praktyki Pielęgniarskiej (ICNP®) w praktyce pielęgniarskiej. Warszawa: Wyd. Lekarskie PZWL; 2014, s. 98-137.

3. Ślusarska B. Implementacje praktyczne wybranych klasyfikacji diagnoz i interwencji pielęgniarskich dla pielęgniarstwa polskiego. Zdrowie Publiczne i Zarządzanie. 2016;14 (1): 11-22.

4. Cisek M. i wsp. red. Opieka nad chorymi terminalnie. Towarzyszenie w godnym umieraniu. Katalog ICNP ${ }^{\circledast}$. Międzynarodowa Rada Pielęgniarek, PolskieTowarzystwo Pielęgniarskie 2009: http://www.ptp.na1.pl/pliki/KonferencjalCNP/INCP_katalog_ paliatywna.pdf [dostęp z dn. 01.05.2019]

5. Kilańska D, Gaworska-Krzemińska A. Międzynarodowa Klasyfikacja Praktyki Pielęgniarskiej ICNP - istota, założenia, znaczenie, rozwój. [w:] Kilańska D,red. Międzynarodowa Klasyfikacja Praktyki Pielęgniarskiej (ICNP ${ }^{\circledast}$ ) W praktyce pielęgniarskiej. Warszawa: Wyd. Lekarskie PZWL; 2014, s. 19-41.

6. www.practest.com.pl/ais-skala-akceptacji-choroby [dostęp z dn. 24.04.2019]

7. Antczak-Domagała K, i wsp. Stan odżywienia oraz sposoby jego oceny u osób w podeszłym wieku i u chorych otępiałych. Pychiatr Psychol Klin. 2013;13(4): 271277.

8. Nursing Outcome Indicators. International Classification for Nursing Practice (ICNP ${ }^{\oplus}$ Catalogue. International Council of Nurses. Genewa 2011.

9. Zarzycka D, i wsp. Katalog skal i kwestionariuszy do oceny stanu zdrowia dla potrzeb opieki pielęgniarskiej. Lublin 2015; s. 92-93.

10. https://www.icn.ch/what-we-do/projects/ehealth/icnp-browser?fbclid=IwAR3X uSX58DZ5HTfPXZzoB0jvZG75F4ffWr5FEUIwXKAS1eIXbG7_mfXDm0xo [dostęp z dn. 01.05.2019].

11. Grabowska H, Kilańska D, Gaworska-Krzemińska A. Metoda pracy pielęgniarki w praktyce klinicznej. Proces pielęgnowania i zastosowanie terminologi referencyjnej. [w:] Kilańska D, Grabowska H, Gaworska-Krzemińska A, red. E-zdrowie. Wprowadzenie do informatyki w pielęgniarstwie. Warszawa: Wyd. Lekarskie PZWL; 2018, s.367-396.

12. Ikwanty K, Dobrowolska B. Wykorzystanie Międzynarodowej Klasyfikacji Praktyk Pielęgniarskiej (ICNP®) w diagnozowaniu pacjenta Oddziału Intensywnej Opieki Medycznej. Piel XXI w. 2012; 1(38): 67-71. 
13. Kilańska D, Niemiec L, Brosowska B. Studium przypadku dziecka z ostrą białaczką limfoblastyczną w czasie chemioterapii. Część I - zastosowanie ICNP®. Probl Piel.2015; 1(23): 81-86.

14. Kilańska D, Staszewska M, Urbanek N. i wsp. Planowanie opieki według międzynarodowego standardu ICNP ${ }^{\oplus}$ w Podstawowej Opiece Zdrowotnej - studium przypadku. Probl Piel. 2014; 4(22): 539-545.

15. Grabowska H, Grabowski W, Gaworska-Krzemińska A. Wykorzystanie ICNP ${ }^{\oplus}$ W opiece pielęgniarskiej nad pacjentem z nadciśnieniem tętniczym. Probl Piel. 2015; 22(1): 107-112.

16. Babska K. Międzynarodowa Klasyfikacja Praktyki Pielęgniarskiej - ICNP ${ }^{\otimes}$ przyszłość polskiego pielęgniarstwa nefrologicznego. Forum Nefrol. 2015; 1: 49-54

17. Ślusarska B, i wsp. Wartość praktyczna klasyfikacji diagnoz pielęgniarskich ICNP ${ }^{\otimes}$ i NANDA w opinii studentów pielęgniarstwa. Pielęgniarstwo Polskie 2017; 3(65):416-421.

18. Furtado LG, Medeiros ACT, Nóbrega MML. Terminological subset of the international classification for nursing practice: an integrative review. Braz J Nurs. 2013; 12(1): 178-193.
Manuscript received/Praca zgłoszona do czasopisma: 13.05.2019

Manuscript accepted/Praca zaakceptowana do druku: 07.07.2019

Translation/Tłumaczenie: Beata Chrust 